\title{
DOKUMENTARNI FILMOVI KAO INSTRUMENTI PROMOCIJE ODRŽIVE MODE
}

\section{Mirela Holy}

PREGLEDNI ZNANSTVENI RAD / DOI: 10.20901/ms.12.24.6 / PRIMLJENO: 20.8.2020.

SAŽETAK Održiva moda je društveno i okolišno odgovorna moda, ekonomski uspješna te etična u odnosu prema prirodi, drugim živim bićima i ljudima. Rezultati istraživanja stavova hrvatskih dizajnera o konceptu održive mode u 2017. godini pokazali su da se većina ispitanika upoznala s tim konceptom u dokumentarnim filmovima (Holy i Borčić, 2018). To ne čudi jer ima mnogo atraktivnih dokumentarnih filmova na temu modne neodrživosti i promocije održivih modnih koncepata. Ovaj rad istražuje kako šest dokumentarnih filmova uokviruje koncept održive te brze/jeftine mode, koji se emocionalni apeli koriste u filmovima, kako se koriste narativi te kako je moda općenito prikazana. Analiza sadržaja provedena je na sljedećim dokumentarnim filmovima: True Cost, The Next Black, Slow Down Fast Fashion, Unravel, River Blue $i$ Do we change it? Ethical fashion documentary. Istraživanje je pokazalo kako se u dokumentarnim filmovima o modnoj industriji koriste manipulativne tehnike uvjeravanja, ali nedovoljno integriraju publike, što može utjecati na njihovu učinkovitost. 


\section{UVOD}

Najveća su globalna prijetnja današnjice klimatske promjene uzrokovane prekomjernim emisijama stakleničkih plinova dominantno u sektorima energetike i prometa, industrijskih procesa i uporabe proizvoda, poljoprivrede i gospodarenja otpadom (Ministarstvo gospodarstva i održivog razvoja, 2018). Klimatske su promjene posljedica društvenoekonomskog sustava kojim dominira trend konzumerizma kao puta do ostvarivanja sreće i zadovoljstva pojedinca. Tomić-Koludrović i Leburić $(2002$, str. 31) tvrde da je „potrošačka kultura" presudna za razumijevanje suvremenog društva. Naime, konzumerizam sa svim svojim ekonomskim, društvenim, psihološkim, kulturološkim i etičkim učincima jest najistaknutiji fenomen suvremenog globaliziranog društva u kojem živimo (Webb, 2012). Sve veća proizvodnja dovodi do pojeftinjenja i veće dostupnosti proizvoda, što mnogi smatraju pozitivnim trendom demokratizacije potrošnje (Lury, 1996), no taj fenomen ima kataklizmičke posljedice na klimu, siromašenje resursa i degradaciju svih čimbenika okoliša.

Modna je industrija jedna od okolišno, ali i socijalno najinvazivnijih industrija (Hoskins, 2015), jedna od industrija koje se najviše oslanjaju na konzumerizam te direktno putem svojih promotivnih sadržaja promiče ideje prema kojima su zadovoljstvo i sreća pojedinca te njegova prihvaćenost u društvu izravno povezani s odjevnim predmetima koje pojedinac nosi i vrlo često mijenja. Ta kontinuirana promjena modnih trendova sa sve kraćim trajanjem "sezona“ podrazumijeva proizvodnju iznimno velikog broja odjevnih proizvoda, njihove sve kratkotrajnije upotrebe, sve niže kvalitete i sve niže cijene za potrošače, ali po sve većoj cijeni za okoliš, prirodu i resurse, kao i zaposlenike u modnoj industriji. Posebno zabrinjava proizvodnja brze, odnosno jeftine mode u "sweatshop" ${ }^{\prime \prime}$ pogonima poput Rana Plaze u čijem su rušenju 24. travnja 2013. godine poginule 1134 radnice i radnika (Clean Clothes Campaign, bez. dat.). Trend tzv. brze ili jeftine mode doveo je do toga da su ljudi 2014. godine prosječno kupili 60\% više odjevnih predmeta no 2000. godine (Remy i dr., 2016) a taj mahniti odjevni konzumerizam progresivno raste iz godine u godinu. Niske cijene proizvoda vode potrošače do impulzivnih kupovina i neodrživog ponašanja: pretjerane potrošnje, vrlo kratkog vremena uporabe proizvoda i preranog odlaganja proizvoda (Niinimäki, 2013). Upravo je zbog toga modna industrija 2018. godine emitirala 10\% ukupnih antropogenih emisija stakleničkih plinova (European Parliament, 2020). Zbog kontinuiranog rasta potrošnje tekstilnih proizvoda, rastu i količine otpadnog tekstila te otpadne obuće, što predstavlja velik okolišni problem. I Hrvatska je dio toga globalnog trenda, što je vidljivo i iz Izvješća o gospodarenju otpadnim tekstilom i otpadnom obućom u 2019. godini (Ministarstvo gospodarstva i održivog razvoja, 2020) prema kojem je u 2018. godini u Hrvatskoj ukupno proizvedeno 60.190 tona otpadnog tekstila od kojeg je odvojeno prikupljeno tek 12.061 tona. Ti se podatci evidentiraju od 2010. godine, a od te je godine vidljiv kontinuiran rast količine otpadnog tekstila. Svaki stanovnik Hrvatske proizvede čak $12 \mathrm{~kg}$ otpadnog tekstila godišnje. U 2019. godini na odlagališta je odloženo visokih 64 \% ukupne količine proizvedenog otpadnog tekstila i otpadne obuće (25), što samo potvrđuje tvrdnje o neodrživosti sadašnje modne industrije.

\footnotetext{
${ }^{1}$ Leksikon marketinga koji je uredio Jozo Previšić „sweatshop“ prevodi riječju 'znojnica', u značenju tvornice u kojoj manualni radnici rade loše plaćene poslove u iznimno lošim radnim uvjetima.
} 
Trend brze/jeftine mode danas je globalno prisutan jer su proizvodi svjetskih korporativnih tzv. high street marki gotovo istovremeno dostupni u New Yorku, Zagrebu i Manili. Brza ili jeftina moda predstavlja proizvodnju jeftinijih verzija odjeće koja često uključuje iskorištavanje jeftine radne snage u takozvanim nerazvijenim zemljama, uglavnom za prodaju po niskim cijenama u bogatijim zapadnim zemljama i uz veliku štetu prirodi i okolišu. Trend brze/jeftine mode relativno je nov trend, a globalno je prisutan u posljednjih tridesetak godina (Cline, 2012).

Trend održive mode također se razvija u posljednjih tridesetak godina, gotovo istodobno s trendom brze/jeftine mode. Održiva moda se kao svojevrsna implementacija ideje održivog razvoja u području modne industrije razvijala istodobno s konceptom održivog razvoja. Održivi je razvoj integrativni koncept koji razmatra ekološke, društvene i ekonomske aspekte kao tri temeljne dimenzije, odnosno stupove održivosti koji podrazumijevaju odgovoran razvoj uz razmatranje prirodnog, ljudskog i ekonomskog kapitala ili, kolokvijalno govoreći, planeta, ljudi i profita (Hansmann i sur., 2012, str. 451). S obzirom na činjenicu da održivi razvoj podrazumijeva ravnotežu između tri stupa na kojima počiva svako društvo - gospodarskog, okolišnog i društvenog, tako i održiva moda podrazumijeva uravnoteženost ekonomskih ambicija, potrajnog korištenja prirodnih resursa i društvene pravednosti modne industrije. Kao sinonimi za pojam održiva moda koriste se i izrazi kao što su zelena ili ekomoda, etična, kružna/cirkularna i spora moda. Fenomen održive mode pojavio se krajem 80 -ih, početkom 90 -ih godina prošlog stoljeća, kada su modni brendovi Patagonia i Esprit, zabrinuti zbog negativnog utjecaja modne industrije na okoliš i ljudska prava tekstilnih radnika u takozvanim zemljama trećeg svijeta, pokrenuli trend održivog pristupa modi (Ribeiro Rosa, 2016, str. 11). Održivost unutar tog koncepta „znači da razvojem i uporabom stvari ili procesa nema štete za ljude ili planet" (Hethorn i Ulasewicz, 2009, str. xviii), što je dijametralno suprotno daleko raširenijem konceptu neodržive brze/jeftine mode. Jestratijevic i Rudd (2018) predložile su šest oblika za klasifikaciju održive mode: a) biorazgradivi proizvodi ili proizvodi koji se mogu reciklirati, b) novi luksuzni proizvodi, c) rabljeni i vintage proizvodi, d) popravljeni, reciklirani i nadograđeni proizvodi, e) etički izrađeni proizvodi te f) službeno certificirani proizvodi, odnosno Fair Trade proizvodi.

Upravo zbog iznimno štetnih posljedica modne industrije na prirodni, ali i društveni okoliš u zemljama u razvoju, modna industrija, posebice tzv. high street brendovi koji se ubrajaju u jeftinu ili brzu modu vrlo su česta tema dokumentarnih filmova koji se bave zaštitom okoliša. Dokumentarni filmovi koji se bave kritikom brze, odnosno jeftine mode te promocijom održive mode kao održive alternative ubrajaju se u tzv. okolišnu komunikaciju (environmental communication). ${ }^{2}$ Prema Blewittu (2017, str. 390) dokumentarni su filmovi iznimno važan element okolišne komunikacije jer se uz pomoć njih, vještim korištenjem vizualne komunikacije koja je često utemeljena na suprotnostima, nastoji potaknuti gledatelje ne samo na promjenu mišljenja i stavova već na poduzimanje konkretnih akcija.

\footnotetext{
${ }^{2}$ U hrvatskom jeziku ta engleska sintagma prevodi se kao „ekološka komunikacija“, no takav prijevod upućuje na nerazumijevanje i nerazlikovanje termina ekologija kao prirodne znanosti, podvrste biologije koja se bavi odnosima jedinki u okviru nekog staništa, te kompleksnog fenomena zaštite okoliša koji podrazumijeva društveni aktivizam koji se koristi spoznajama ekologije kao znanosti. Stoga, usprkos uvriježenom terminu 'ekološka komunikacija' u ovom se tekstu koristi termin 'okolišna komunikacija', koji je precizniji prijevod navedene sintagme.
} 
Willoquet-Maricondi (2010, str. 45) naglašava da „ekokinematografija otvoreno nastoji potaknuti osobno i političko djelovanje gledatelja, navodeći nas da razmislimo o promjeni načina na koji donosimo odluke o svojim odabirima, svakodnevno i dugoročno, kao pojedinci i kao društvo, lokalno i globalno". S obzirom na činjenicu da okolišna komunikacija ne samo u Hrvatskoj, već i globalno, još uvijek nije dobro istraženo područje, posebice okolišna komunikacija koja problematizira modnu industriju, problem koji se u ovom radu istražuje jest neistraženost dokumentarnih filmova kao instrumenata promocije održive mode te ograničenja takve promocije. Predmet istraživanja jesu odabrani dokumentarni filmovi koji kritiziraju neodrživu modu i promoviraju održive koncepte u modnoj industriji. Cilj ovog istraživanja je istražiti kojim se propagandnim i persuazivnim tehnikama koriste odabrani dokumentarni filmovi koji promoviraju održivu modu, te kako unaprijediti metode uvjeravanja koje se koriste u takvim dokumentarnim filmovima. Specifični ciljevi ovog istraživanja su:

>istražiti kako odabrani dokumentarni filmovi uokviruju koncept održive i brze / jeftine mode;

>istražiti koje emocionalne apele upotrebljavaju;

>istražiti kojim se narativima koriste te kako je moda u odabranim filmovima općenito prikazana;

>istražiti koriste li se odabrani filmovi manipulativnim, propagandnim tehnikama uvjeravanja te;

>predložiti metode uvjeravanja kojima se može unaprijediti persuazivni potencijal takvih filmova.

Istraživanje je provedeno metodom kvalitativne analize sadržaja na sljedećih šest filmova: True Cost, The Next Black, Slow Down Fast Fashion, Unravel, River Blue i Do we change it? Ethical fashion documentary. Ti su filmovi odabrani za analizu jer se na internetskim pretraživačima nalaze na popisima najboljih dokumentarnih filmova na temu održive mode te su bili dostupni autorici članka.

\section{OKOLIŠNA KOMUNIKACIJA}

Dokumentarni su filmovi specifičan nefikcijski žanr koji je krajem prošlog stoljeća postao izuzetno popularan i utjecajan (Grant i Sloniowski, 1998, str. 19). Taj se trend popularnosti dokumentarnih filmova koristio i u propagandne svrhe, pa je mnogim dokumentarnim filmovima svrha propagandna, iako bi njihova svrha trebala biti oprečna propagandi. Naime, prema jednoj od prvih definicija "dokumentarni film je grana filmske produkcije koja polazi od realnosti, fotografira je, uređuje i oblikuje (...), pokušava dati oblik i uzorak kompleksnosti izravnog promatranja" (Grierson, 1946, prema Hardy, 1946, str. 159), što podrazumijeva pokušaj prenošenja objektivnih informacija o fenomenu koji se razmatra. lako je popularnost dokumentarnih filmova moderan trend, uporaba dokumentarnih filmova u propagandne svrhe nije. Naime, mnogi totalitarni režimi i diktature koristili su se propagandnim dokumentarnim filmovima kao instrumentima "proizvodnje pristanka" 
(Bernays, 1947, str. 113). Na primjer, jedan je od najpoznatijih nacističkih propagandnih filmova dokumentarni film Trijumf volje iz 1935. godine koji je režirala Leni Riefenstahl, a i Sovjetski Savez koristio se dokumentarnim filmovima u svrhu političke propagane pa tako Lee-Wright (2010, str. 164) tvrdi da su "Lenjin i politbiro prepoznali kino kao najučinkovitije sredstvo angažiranja i uključivanja masa različitih ljudi u zajedničke ciljeve i stavove." No, dokumentarnim se filmovima kao propagandnim instrumentima koriste ne samo totalitarni već i demokratski režimi. Razlika je u tome što se takvi sadržaji u demokratskim društvima smatraju edukacijom, moralnom podukom ili građenjem karaktera, a nikako ne indoktrinacijom (Chomsky, 2002, str. 124). Bez obzira na deklarirani objektivni predznak dokumentarne filmografije činjenica jest da su se dokumentarni filmovi i u prošlosti koristili, a i danas se koriste kao više ili manje učinkovita sredstva manipulativne komunikacije. Istraživači su s rastom popularnosti dokumentarnih filmova, posebice onih s okolišnom tematikom, počeli istraživati koliko su dokumentarni filmovi učinkoviti u smislu utjecaja na stavove i mišljenja, a posljedično i ponašanja publika. Karlin i Johnson (2011) su zaključili da promjene u komunikaciji, pojava digitalne komunikacije, društvenih mreža i konvergencije medija s jedne strane omogućuju, a s druge strane onemogućuju procjenu utjecaja dokumentarnih filmova na pojedine gledatelje i društvo. Naime, analiza uspješnosti takvih filmova prije je bila ograničena na brojeve prodanih karata na kinoblagajnama, recenzije, novinske kritike te anketiranje gledatelja prilikom izlaska iz kina. Međutim, s rastom utjecaja novih medija pružila se mogućnost povezivanja i integriranja filmaša, aktivista i gledatelja na nove načine, a time ukazala potreba za novim načinima mjerenja uspješnosti dokumentarnih filmova. Karlin i Johnson (2011) smatraju da dokumentarni filmovi imaju velik potencijal utjecanja na društvene i okolišne potrebe. Posebno naglašavaju potrebu za društveno znanstvenim pristupom koji kombinira empirijsku analizu s teorijom primijenjenom iz osnovne znanosti, a koja može osigurati da se utjecaj dokumentarnog filma mjeri na način koji je koristan i za filmaše i za financijere filma.

Okolišna komunikacija često se smatra komunikacijom koja nužno u sebi nosi etičnu dimenziju pa tako Cox (2007, str. 5) tvrdi da je etička dimenzija okolišne komunikacije primarna te da je glavna etička dužnost te komunikacije „obveza povećanja sposobnosti društva da na odgovarajući način reagira na signale iz okoliša relevantne za dobrobit ljudskih zajednica i prirodnih bioloških sustava“. No, kako bi se to postiglo, a imajući na umu da živimo u svijetu u kojem su informacije, jako često manipulativne, ključan instrument društvene promjene, onda ni teoretičari okolišne komunikacije ne odbijaju a priori korištenje manipulativnih komunikacijskih taktika. Tako, primjerice, Blewitt (2017, str. 405) na pitanje "Može li se održivost prodavati?" bez ikakve zadrške odgovara sa "da“, te naglašava kako se održivost mora učinkovito promicati. Da bi se održivost učinkovito promicala, okolišna komunikacija mora se koristiti onim tehnikama i metodama koje su najučinkovitije u procesu uvjeravanja, a one su često iznimno manipulativne. Stoga se i okolišni dokumentarni filmovi koriste manipulativnim metodama komunikacije kako bi postigli svoje ciljeve. Druga razina problema okolišne komunikacije ne odnosi se na komunikacijsku strategiju i odabrane taktike za implementaciju strategije, već na stvarne ciljeve takve komunikacije. Drugim riječima, neka komunikacija može se prikazivati kao okolišna, no njezina stvarna svrha ne mora nužno biti okolišna, već može biti prodajna, što je u literaturi poznato kao 
"green washing", zeleno pranje koje ima namjeru obmanuti publiku. Stoga je za potrebe ovog rada, i to prije no što se razmotri kolika je učinkovitost okolišnih dokumentarnih filmova, nužno definirati što je to uopće okolišna komunikacija.

Cox (2010, str. 20-21) okolišnu komunikaciju definira kao „pragmatično i konstitutivno sredstvo za razumijevanje okoliša i naših odnosa prema prirodnom svijetu“. Prema njemu okolišna je komunikacija simbolički medij kojim se koristimo za izgradnju razumijevanja problema okoliša, ali i dogovaranja različitih društvenih odgovora na njih. Stoga Cox smatra kako okolišna komunikacija ima dvije različite funkcije: pragmatičnu i konstitutivnu. Pragmatična funkcija podrazumijeva edukaciju, upozoravanje, nagovaranje, mobiliziranje i pomaganje u rješavanju konkretnih ekoloških problema. Cox ilustrira pragmatičnu funkciju okolišne komunikacije primjerom medijskih kampanja proizvođača automobila protiv viših standarda emisija goriva ili kad ekološka skupina ima kampanju u cilju zaštite područja divljine. To je komunikacija koja se usredotočuje na posebno, na izdvojene slučajeve. Konstitutivna funkcija pomaže u definiranju određenih okolišnih pitanja kao problema. Konstitutivna komunikacija povezuje univerzalne vrijednosti s okolišnim problemima i tako pomaže publici u izgradnji reprezentacije izazova vezanih za održivost, prirodu i okoliš kao predmeta spoznaje. To je komunikacija koja se usredotočuje na opće i univerzalno.

Dokumentarni filmovi s okolišnom problematikom bez ikakve se sumnje snimaju kako bi utjecali na mišljenja i stavove javnosti i pri tome informirali, uvjeravali i poticali na akciju. Janpol i Dilts (2016) željeli su istražiti koliko su takvi filmovi učinkoviti u utjecanju na gledatelje. Naime, iako ljudi koji snimaju dokumentarne filmove s okolišnom problematikom uglavnom pretpostavljaju da će njihova djela utjecati na stavove i postupke ljude, ne postoji empirijsko opravdanje za takve pretpostavke. Stoga je svrha njihove studije bila saznati hoće li gledanje dokumentarnog filma utjecati na percepciju ljudi o okolišu i na njihovo ponašanje. Njihovo je istraživanje uključivalo gledanje ili filma o dupinima ili filma o obnovi slavnog Golden Gate mosta koji je poznata atrakcija San Francisca. Nakon što su ispitanici gledali filmove, igrali su računalnu igru, a na temelju njihovih rezultata napravljena je procjena njihove okolišne identifikacije. Nakon toga je ispitanicima ponuđena mogućnost sudjelovanja u dobrotvornim akcijama za pomoć dupinima ili pak za obnovu mosta. Rezultati su pokazali značajne razlike između angažmana ispitanika koji su gledali dokumentarni film o dupinima te onih koji su gledali film o mostu. Naime, daleko veći utjecaj na ispitanike imao je film o dupinima ne samo na informativnoj razini već i na razini poticanja na akciju, odnosno donaciju.

Druga istraživanja učinkovitosti okolišnih dokumentarnih filmova pokazala su drugačije rezultate. Primjerice, Howell (2014) je procjenjivala učinkovitost komunikacije o klimatskim promjenama, odnosno dugoročni utjecaj na stavove i ponašanje pojedinaca takve komunikacije. Njeno je istraživanje longitudinalna studija utjecaja filma o klimatskim promjenama The Age of Stupid, hibrida dokumentarnog, igranog i animiranog britanskog filma iz 2009. godine, na britanske gledatelje. Istraživanje je pokazalo da početna pojačana razina zabrinutosti i motivacije gledatelja za promptnim djelovanjem nakon gledanja filma nije imala dugotrajni učinak. Rezultati istraživanja također su pokazali da se namjere prema promjeni ponašanja nužno ne pretvaraju u konkretne akcije. 
Nolan (2010) je istraživala učinkovitost jednog od najpoznatijih dokumentarnih filmova s okolišnom problematikom, An Inconvenient Truth iz 2006. godine, bivšeg američkog potpredsjednika Ala Gorea. Vidljivost filma bila je osigurana samom činjenicom što je autor filma poznata osobu, a metoda 'poznati govore' (testimonials) jedna je od najpoznatijih i najkorištenijih propagandnih tehnika. An Inconvenient Truth su, naglašava Nolan, pogledali milijuni ljudi, a neke su zemlje čak predložile da se film koristi kao obavezni obrazovni sadržaj u školama. Međutim, rezultati istraživanja nisu nedvosmisleno pokazali da film utječe na rast informiranosti i svijesti gledatelja o uzrocima klimatskih promjena, posebice ne na motivaciju ljudi da smanje emisije stakleničkih plinova. Istraživanje se temeljilo na dvije studije. $U$ jednoj su ispitanici bili gledatelji iz lokalne zajednice, a u drugoj studenti. Rezultati pokazuju da gledanje filma povećava informiranost ispitanika o uzrocima globalnog zagrijavanja, te utječe na njihova uvjerenja o nužnosti brige za okoliš i njihove osobne spremnosti za smanjenje emisija stakleničkih plinova. Međutim, rezultati također sugeriraju kako se ta spremnost za akciju odmah nakon gledanja filma ne održava dugoročno, odnosno da značajno pada već mjesec dana kasnije. Autorica smatra kako je snaga filma u uvjerljivoj prezentaciji činjenica o kontinuiranom rastu globalnih temperatura te pozivu na akciju. Stoga zaključuje kako je film postigao svoj cilj, a to je uvjeriti ljude u nužnost suzbijanja klimatskih promjena. No, naglašava kako je velik izazov s kojim su suočeni oni koji se žele koristiti dokumentarnim filmom kao obrazovnim i motivacijskim sredstvom pronalaženje načina kako učinkovito iskoristiti povećanu motivaciju masa za postizanje značajnog smanjenja emisija stakleničkih plinova.

I mnoga druga istraživanja i studije pokazali su slične rezultate. Primjerice, Jacobsenova studija (2011) pokazala je kako je dokumentarni film Ala Gora dva mjeseca nakon emitiranja filma lokalno utjecao na porast kupnje dobrovoljnih kompenzacija ugljika, no godinu dana kasnije broj kompenzacija ugljika vratio se na prijašnju razinu, što pokazuje da je Goreov film tek privremeno utjecao na ponašanje gledatelja.

Harness i Drossman (2011) istraživali su koliko osobno iskustvo u stvaranju dokumentarnih filmova utječe na mišljenje i stavove studenata o okolišu. Njihova je pretpostavka bila da studenti nakon izlaganja informacijama o klimatskim rizicima postaju apatični prema pitanjima zaštite okoliša jer su uvjereni kako nemaju nikakvu moć utjecaja na pozitivne promjene. Naime, takve rezultate pokazala su mnoga istraživanja utjecaja okolišne komunikacije na ponašanje publika, odnosno što publika ime više spoznaja o okolišnim problemima, smanjuje se njezina motivacija za okolišno djelovanje (Heimlich, 2010; Hungerford i Volk, 1990; Kellstedt i sur., 2008). Studija Harness i Drossmana (2011) pokazala je kako su ispitanici nakon izrade dokumentarnih filmova izrazili pojačanu motivaciju za aktivizmom u području okolišnog djelovanja, odnosno da ispitanici stvaraju znanje o okolišu putem društvenih procesa koji uključuju međusobno povezane utjecaje škole, obitelji i medija; da je apatija prema okolišu uobičajena među ispitanicima koji se percipiraju kao pripadnici rizičnih skupina te koji smatraju kako njihova školska sredina nije usredotočena na obrazovanje o okolišu; te da ispitanici spremnije prihvaćaju okolišno odgovorno ponašanje ako im se pruži prilika za razvijanje vlastitog razumijevanja povezanosti između osobnih radnji i pridruženih posljedica na okoliš. 
Drugim riječima, da bi okolišna komunikacija bila učinkovita nije dovoljno publike tretirati kao pasivne konzumente informacija o okolišu, čak ni ako su metode uvjeravanja učinkovite jer to ne rezultira dugoročnim promjenama u ponašanju. Kako bi okolišna komunikacija postala učinkovita nužno je publike na neki način osobno integrirati u okolišnu komunikaciju i/ili okolišnu akciju.

\section{ANALIZA SADRŽAJA DOKUMENTARNIH FILMOVA}

lako termin propaganda zbog nacističkih konotacija ima izrazito negativnu percepciju u javnosti, Šiber (2003, str. 144) upozorava na to da bi propagandu trebalo doživljavati kao tehnologiju koja je vrijednosno neutralna i koja je usmjerena ostvarenju cilja. Slično mišljenje imaju i mnogi drugi teoretičari odnosa s javnošću koji ne vide (veliku) razliku između prakse odnosa s javnošću i propagande (Kunczik, 2006, str. 11-16). Danas prevladava stav prema kojem je osnovna svrha odnosa s javnošću uvjeravanje (persuazija), ono što Bernays zove "generiranje suglasja", odnosno dijalog različitih mišljenja (Tkalac Verčič, 2015, str. 121). Prema tom gledištu propaganda je promišljena i planirana jednosmjerna komunikacija čija je svrha osigurati nekritičko prihvaćanje, odnosno sustavan pokušaj oblikovanja ljudske percepcije, svojevrsna manipulacija ponašanja (Škarica, 2012, str. 9-14), a odnosi su s javnošću upravljanje dvosmjernom komunikacijom koje se temelji na persuazivnim tehnikama kako bi se zadovoljile potrebe i onih koji uvjeravaju i onih koje se uvjerava (Šiber, 2003, str. 145). Šiber (2003) propagandne tehnike dijeli u dvije skupine: one koje variraju emocionalne komponente stava i one koje naglašavaju osjećaje ugroženosti i nesigurnosti. $U$ tehnike emocionalne komponente stava ubraja sljedeće tehnike: emocionalni sendvič, prijenos emocija koji podrazumijeva učestalo ponavljanje neutralnog sadržaja u kombinaciji s pozitivnim čime se postiže prijenos pozitivnih emocija i na neutralni sadržaj, tehnika povezanih stavova, emocionalno otežane riječi, zamjenu imena, upotreba stereotipa, upotreba seksualnosti i erotike. U tehnike naglašavanja ugroženosti ubraja upotrebu autoriteta, popularnost pojedinih osoba te manipulaciju konformizmom (2003, str. 149-154). Bez obzira na proklamirane ambicije prema zadovoljavanju potreba svih strana koje sudjeluju u komunikacijskom procesu, činjenica jest da je i danas glavna svrha većine planiranih komunikacija upravo pokušaj oblikovanja željene ljudske percepcije te je u skladu s time provedena i analiza odabranih dokumentarnih filmova: True Cost, The Next Black, Slow Down Fast Fashion, Unravel, River Blue i Do we change it? Ethical fashion documentary. Jedinica analize bio je dokumentarni film koji promovira održivu modu. Analitička matrica analize sadržaja odabranih dokumentarnih filmova koji promoviraju održivu modu temeljila se na sljedećim kvalitativnim elementima: koje propagandne tehnike uvjeravanja i emocionalne apele filmovi koriste, na koji način uokviruju koncept održive i brze / jeftine mode i mode općenito; te koje narative koriste. U istraživanju su u cilju usporedbe analiziranih filmova iskorišteni i dostupni sekundarni podatci kvantitativnog predznaka, odnosno godina proizvodnje, trajanje filma, izvori financiranja, zemlja porijekla i redatelji te broj preuzimanja kod onih filmova kod kojih su ti podatci dostupni. 


\section{Usporedba sekundarnih podataka kvantitativnog predznaka}

U Tablici 1., 2. i 3. prikazani su podatci o godini proizvodnje, trajanju filmova, zemlji porijekla i redateljima te izvorima financiranja i broju pregleda kod onih filmova kod kojih su ti podatci dostupni.

Tablica 1. Sekundarni podatci kvantitativnog predznaka

\begin{tabular}{|c|c|c|c|}
\hline Naziv & Trajanje & Država i godina proizvodnje & Redatelj \\
\hline True Cost & $92 \mathrm{~min}$ & SAD, 2015 & Andrew Morgan \\
\hline The Next Black & $47 \mathrm{~min}$ & Švedska/SAD, 2014 & David Dworsky \\
\hline Slow Down Fast Fashion & $65 \mathrm{~min}$ & $\begin{array}{l}\text { Ujedinjeno Kraljevstvo/Francuska/ } \\
\text { SAD, } 2016\end{array}$ & Ben Akers \\
\hline Unravel & $14 \mathrm{~min}$ & Ujedinjeno Kraljevstvo/Indija, 2012 & Meghna Gupta \\
\hline River Blue & $95 \mathrm{~min}$ & Kanada, 2017 & $\begin{array}{l}\text { David Mcllvride, } \\
\text { Roger Williams }\end{array}$ \\
\hline $\begin{array}{l}\text { Do we change it? Ethical } \\
\text { fashion documentary }\end{array}$ & $53 \mathrm{~min}$ & Španjolska, 2015 & $\begin{array}{l}\text { Carlos Isabel } \\
\text { La Moneda }\end{array}$ \\
\hline
\end{tabular}

Izvor: istraživanje autorice

Iz tablice 1. je vidljivo kako su analizirani filmovi nastali većim dijelom u zapadnim kapitalističkim državama: SAD, UK, Švedskoj, Francuskoj, Kanadi i Španjolskoj u kojima su uglavnom i smještene najmoćnije modne multinacionalne korporacije. Izuzetak je Indija koja se ubraja u skupinu država u kojima modne multinacionalne korporacije najčešće imaju „sweatshop-ove“ u kojima se šivaju proizvodi brze/jeftine mode. Što se tiče trajanja analiziranih filmova, prosječna im je duljina 61 min. Po duljini trajanja odskaču River Blue (95 min) i True Cost (93 min) te po trajanju najkraći Unravel (14 min). Samo je jedna redateljica, i to Meghna Gupta, redateljica najkraćeg Unravela. lako je modna industrija često percipirana kao područje ženskog interesa na temelju čega bi se mogao očekivati veći broj ženskih redatelja, činjenica je da su i danas redatelji većinom muškarci, što se reflektira i na ovo područje analize. Svi analizirani filmovi snimljeni su u posljednjem desetljeću, što koincidira s eksponencijalnim rastom proizvodnje i potrošnje odjevnih proizvoda i, posljedično, rastom zabrinutosti zbog tog fenomena. Najstariji film je Unravel koji je snimljen 2012. godine, a najmlađi River Blue iz 2017. godine.

Tablica 2. Izvori financiranja

\begin{tabular}{ll} 
Naziv & Izvori financiranja \\
True Cost & $\begin{array}{l}\text { Crowd funding kampanja, preuzimanje filma na digitalnim } \\
\text { kanalima se naplaćuje. }\end{array}$ \\
\hline The Next Black & AEG korporacija \\
\hline Slow Down Fast Fashion & $\begin{array}{l}\text { Nije dostupna informacija, preuzimanje filma na digitalnim } \\
\text { kanalima se naplaćuje. }\end{array}$ \\
\hline
\end{tabular}




\begin{tabular}{ll} 
Naziv & Država i godina proizvodnje \\
Unravel & Nije dostupna informacija \\
\hline River Blue & Ima korporativne (The Explorers Club, Inpired Image Picture \\
& $\begin{array}{l}\text { Company, Mountain Equipment) i individualne izvore } \\
\text { financiranja, a podatci su dostupni na web stranici filma, } \\
\text { preuzimanje filma na digitalnim kanalima se naplaćuje. }\end{array}$ \\
\hline $\begin{array}{l}\text { Do we change it? Ethical } \\
\text { fashion documentary }\end{array}$ & Popis financijera je dostupan na odjavnoj špici filma i \\
& obuhvaća zelene zaklade i pojedince. \\
\hline
\end{tabular}

Izvor: istraživanje autorice

Iz Tablice 2. je vidljivo kako se preuzimanje tri (River Blue, Slow Down Fast Fashion i True Cost) od šest analiziranih filmova naplaćuje, što je u kontradikciji s proklamiranom svrhom okolišnih dokumentarnih filmova, a to je što veća vidljivost i informiranost publika kako bi se postiglo pozitivne društvene promjene. Podatci iz tablice upućuju i na nedovoljnu transparentnost u objavi izvora financiranja, što nije u skladu s etičkim načelima okolišne komunikacije.

Tablica 3. Broj pregleda na YouTube-u na dan 02. srpnja 2018.

\begin{tabular}{|c|c|}
\hline Naziv & Broj pregleda \\
\hline True Cost & $\begin{array}{l}\text { Nije dostupan na YouTube kanalu, najava filma } \\
\text { ima } 1.792 .222 \text { pregleda. }\end{array}$ \\
\hline The Next Black & 1.251.635 pregleda na YouTube kanalu \\
\hline Slow Down Fast Fashion & $\begin{array}{l}\text { Nije dostupan na YouTube kanalu, najava filma je } \\
\text { pregledana } 347.926 \text { puta. }\end{array}$ \\
\hline Unravel & 131.612 pregleda na YouTube kanalu \\
\hline River Blue & $\begin{array}{l}\text { Nije dostupan na YouTube kanalu, najava filma } \\
\text { ima } 63.695 \text { pregleda. }\end{array}$ \\
\hline Do we change it? Ethical fashion documentary & 9.450 pregleda na YouTube kanalu \\
\hline
\end{tabular}

Iz Tablice 3. je vidljivo kako je publici od odabranih filmova najzanimljiviji True Cost koji je, nažalost, na YouTube kanalu dostupan samo u obliku najave. Po iskazanom interesu slijedi AEG-ov dokumentarac The Next Black što se, možda, može zahvaliti i promišljeno odabranom nazivu filma. Samo ta dva filma ostvarila su više od milijun pregleda na YouTube kanalu, što možda upućuje i na nezainteresiranost publika za takve sadržaje.

\section{Kvalitativna analiza dokumentarnih filmova}

lako analiza sadržaja kao metoda istraživanja u društvenim znanostima može biti i kvalitativna i kvantitativna metoda (Tkalac Verčič i dr., 2014, str. 91-92), za potrebe ovog istraživanja koristila se kao kvalitativna metoda. Istraživanje se usredotočilo na pitanje 
kako analizirani filmovi uokviruju koncept održive i brze/jeftine mode te jesu li u korištenju emocionalnih apela i narativa manipulativni i uvjerljivi, kako bi se na temelju rezultata istraživanja predložilo metode uvjeravanja kojima se može unaprijediti persuazivni potencijal takvih filmova. Analiza sadržaja je često korištena metoda prikupljanja primarnih podataka, posebice je razvijena u području analize masovne komunikacije u koju se ubrajaju i dokumentarni filmovi. Analiza sadržaja se u pravilu usredotočuje na analizu sadržaja poruke, no preko analiza sadržaja poruke moguće je promišljati „i učinke poduzetih akcija" (Tkalac Verčič i dr., 2014, str. 92). Kvalitativna analiza sadržaja odabranih dokumentarnih filmova temeljila se na sljedećim elementima: propagandnim tehnikama uvjeravanja i emocionalnim apelima, načinima uokvirivanja koncepta održive i brze/jeftine mode i mode općenito, te korištenim narativima. 'Uokvirivanje' je koncept koji govori o načinu prezentacije vijesti kroz sugeriranje interpretacijskog okvira (frame), kroz kojeg se selektiraju i obrađuju informacije, prije svega oslanjajući se na zapamćene podatke i iskustva te interpretaciju novih događaja uz pomoć tih klasificiranih, organiziranih i interpretiranih životnih iskustava kojima je pridodan smisao. Uokvirivanjem se naglašavaju određeni aspekti stvarnosti, dok se druge ignorira ili im se umanjuje važnost (Kunczik i Zipfel, 2006). Medijsko uokvirivanje se oslanja na vještinu pričanja priča (storytelling), a teoretičari poput Goffmana (1986), Tobiasa (1993), Bookera (2006) i Lulea (2001) naglašavaju kako narativi ili master mitovi u velikoj mjeri osnažuju manipulativne učinke medijskog uokvirivanja. Prema Bordwellu i Thompson (2011) narativ je svaki niz uzročno-posljedično povezanih događaja koji se odvijaju u nekom vremenu i prostoru.

S obzirom na činjenicu da vizualni sadržaji, pogotovo oni koji koriste kontrastnu metodu, snažno utječu na emocije i stavove publike, okolišni dokumentarni filmovi postali su moćan alat za promociju ideje održivog razvoja i potreba za učinkovitijom zaštitom okoliša. Ti se filmovi intenzivno, promišljeno i planski koriste emocionalnim apelima (strah, suosjećanje, zabrinutost) te propagandnim tehnikama kako bi utjecali na publiku, zbog čega se moglo očekivati da će analiza i modnih okolišnih dokumentarnih filmova pokazati slične rezultate, što je ovo istraživanje i potvrdilo. Slijedi analiza svakog filma pojedinačno, nakon čega je provedena usporedba dobivenih podataka, a rezultati istraživanja interpretirani su i u kontekstu pragmatične i konstitutivne funkcije okolišne komunikacije (Cox, 2010).

True Cost je američki film iz 2015. koji traje 92 minute, a režirao ga je Andrew Morgan. Film uokviruje koncept brze mode kao produkta zapadnog globalnog kapitalizma koji je potpuno neodrživ u smislu zaštite okoliša, uravnotežene raspodjele ekonomskih koristi i socijalnih/ljudskih prava. Kontrastna linija izgrađena je između bogatog zapada (eksploatatora) i siromašnijeg juga i istoka (iskorištavani). Koncept održive mode prisutan je na margini filma, no čak i putem te marginalne prezentacije još je uvijek predstavljen kao moguće rješenje problema neodržive proizvodnje odjeće. Odnos filma prema fenomenu mode općenito je neutralan. Jedna od sugovornica u filmu je Tansy Hoskins, autorica knjige Zašiveno do bola (2015) koja modu smatra "istovremeno veličanstvenom i strašnom" te je zato napisala knjigu „u nadi da će jednog dana biti oslobođena od tržišta te da će je svi moći iskusiti i kroz nju se kreativno izraziti“ (6), a takav odnos prema fenomenu mode može se iščitati i iz filma. Dokumentarac se intenzivno koristi negativnim emocionalnim 
apelima koji su uobičajeni za propagandu: apel straha i zabrinutosti ljudi za zdravlje i budućnost. Narator je Andrew Morgan, redatelj filma. Priča obuhvaća sve segmente lanca opskrbe odjećom, od uzgoja pamuka, bojenja, šivanja do marketinga i maloprodaje. Narativ filma može se podijeliti u tri glavna dijela koji odgovaraju trima stupovima održivog razvoja: ekonomskom (kontinuirano snižavanje cijena odjeće high street brendova na štetu tekstilnih radnika, enormno bogaćenje zapadnih vlasnika tih kompanija), socijalnom (neljudski uvjeti rada i ropska eksploatacija radnika koji šivaju te odjevne predmete u bivšim zemljama tzv. Trećeg svijeta), okolišnom (zastrašujuće razaranje okoliša kao posljedica proizvodnje takve odjeće). Film je sniman na mnogim lokacijama u Velikoj Britaniji, SAD-u, Jamajci, Kambodži, Indiji, Bangladešu, Kini, Danskoj, Japanu, Haitiju, Ugandi s iznimno velikim brojem sudionika, uključujući poznate osobe poput Stelle McCartney. Film se koristi sljedećim propagandnim tehnikama: emocionalni sendvič, prijenos emocija, tehnika povezanih stavova, upotreba stereotipa, upotreba autoriteta, popularnost pojedinih osoba i manipulacija konformizmom.

The Next Black film je iz 2014. godine, nastao u zajedničkoj švedskoj i američkoj produkciji, traje 47 minuta, a režirao ga je David Dworsky. Održiva moda uokvirena je kao moda budućnosti koja je vitalno povezana s tradicijom i prošlosti. U komunikaciji s Rickom Ridgewayom iz održivog modnog brenda Patagonia može se iščitati negativan odnos prema konceptu brze mode, ali kritika brze mode nije dominantan narativ u filmu. Odnos filma prema fenomenu mode općenito je pozitivan. Dokumentarni film ističe tehnološke aspekte održive mode, spoj okoliša i tehnoloških dostignuća. Aspekti ljudskih prava u modnoj industriji nisu dio okvira tog dokumentarnog filma. Film se ne koristi uobičajenim propagandnim apelima na strah, humor, zabavu ili ljubav/seks, već apelira na ljudsku znatiželju i osjećaj odgovornosti. Film ima pripovjedačicu (Hanna Wiederud) koja gledatelje vodi kroz šest poglavlja dokumentarca. Poglavlja su posvećena spajanju tehnologije i mode, kao i modi kao okolišno održivoj praksi, a ispričana su kroz priče o sljedećim modnim markama: Studio XO (Nancy Tilbury), Adidas (Mathew Hymers), BioCouture (Suzanne Lee), Patagonia (Rick Ridgeway), Yeh Group (Sophie Mather), iFixit (Kyle Wiens i Brittany McCrigler). Film upotrebljava sljedeće propagandne tehnike: emocionalni sendvič - emocionalna evokacija na povijest mode (Coco Chanel), praćena je racionalnom porukom te završava emocionalnim krajem; prijenos emocija postiže se ponavljanjem poruka; primjena autoriteta - stručnjaka u dodirnim područjima mode i tehnologije.

Slow Down Fast Fashion dokumentarni je film iz 2016. godine i nastao je u zajedničkoj produkciji Velike Britanije, Francuske i SAD-a. Trajanje filma je 65 min. Redatelj filma je Ben Akers. Film gradi svoj narativ na suprotstavljanju i usporedbi koncepata brze i održive/ etične mode. Taj film, za razliku od filma True Cost, nije usredotočen na brzu modu, već na konkretna rješenja kojima se može postići održiva promjena modne industrije. Odnos prema brzoj modi je negativan, odnos prema održivoj modi izuzetno pozitivan. Film ima pozitivan odnos prema fenomenu mode općenito, što je vidljivo iz uvažavanja modne industrije kao važne gospodarske djelatnosti koja spaja kreativnost i inovativnost sa zaradom. Dokumentarni film podjednako se koristi negativnim i pozitivnim emocionalnim apelima na strah, ljudski osjećaj odgovornosti, suosjećanje, brigu o zdravlju i budućnosti. Narator i glavni protagonist filma je poznati glazbenik Alex James (basist benda Blur). Ja- 
mes putuje u različite zemlje i razgovara s mnogim dizajnerima, aktivistima, stručnjacima, autorima, novinarima, direktorima i predstavnicima high street brendova i predstavlja cijeli niz inovativnih rješenja za ovu "ekološku i moralnu katastrofu", primjerice korištenje vune kao najboljeg održivog tekstila, informacije o izgradnju odnosa s odjećom koju nosimo, produžavanje životnog vijeka odjeće / ponovna upotreba odjeće, recikliranje tekstila itd. Film se služi sljedećim propagandnim tehnikama: emocionalni sendvič, prijenos emocija, tehnika povezanih stavova, upotreba stereotipa, upotreba autoriteta, popularnost pojedinih osoba (Alex James) i manipulacija konformizmom.

Unravel je snimljen 2012. godine u zajedničkoj britanskoj i indijskoj produkciji. Radi se o prilično kratkom filmu koji traje 14 min. Redateljica je Meghna Gupta. Film uspoređuje koncept brze i održive mode. Kontrastna linija izgrađena je između bogatog zapada (brza moda) i siromašnijeg juga (recikliranje odbačene zapadne odjeće). Uokvirivanje se provodi metodom suprotstavljanja neodgovornog i nevidljivog bogatstva i siromaštva s ljudskim licem. Odnos prema brzoj modi je neutralan, odnos prema održivoj modi pozitivan. Odnos prema fenomenu mode općenito nije jasno izražen. Dokumentarac se koristi pozitivnim emocionalnim apelima: suosjećanjem i radovanjem jednostavnim stvarima. Naracija je jednostavna. Priča prati Reshmu, naratoricu, radnicu u tvornici za recikliranje tekstila u Panipatu, malom gradu na sjeveru Indije, te na zapadu odbačenu, velikim dijelom potpuno novu i nenošenu odjeće na putu od lučkog grada Kutch u zapadnoj Indiji do tvornice u Panipatu koja reciklira odbačenu odjeću u pređu i pokrivače. Reshma i druge tekstilne radnice, unatoč vrlo slaboj izloženosti zapadnoj kulturi, na temelju odbačene odjeće koja im prolazi kroz ruke grade sliku Zapada. Film se koristi sljedećim propagandnim tehnikama: tehnikom povezanih stavova koja je vidljiva iz korištenja djece te upotrebom stereotipa koja je vidljiva naglašavanjem kontrasta siromašnih i bogatih zemalja. Taj dokumentarac ne služi se tehnikama naglašavanja ugroženosti i nesigurnosti.

River Blue snimljen je 2017. godine u Kanadi. Film traje 95 min, a režirao ga je David Mcllvride. Dokumentarni film suprotstavlja koncept brze/jeftine mode, prezentirane kao neodržive i neodgovorne mode, konceptu održive mode koja je prezentirana kao potencijalni spasitelj planeta. I u tom filmu odnos prema fenomenu mode općenito nije nedvosmisleno izražen. Kontrastna linija izgrađena je između bogatog zapada (inicijator brze mode, ali i potencijalni kreator ekološki prihvatljivih rješenja) i siromašnijeg juga (proizvođač, ali i žrtva brze mode). Dokumentarni film intenzivno se koristi negativnim emocionalnim apelima uobičajenim za propagandu: strah, zabrinutost za zdravlje i budućnost, kao i ljudski osjećaj odgovornosti. Nevidljivi pripovjedač je poznati kanadski glumac Jason Priestley čiji glas čujemo u offu. Narativ filma povezan je s putovanjem vidljivog pripovjedača, Marka Angela, poznatog aktivista za zaštitu rijeka. Priča o modi ispričana je iz perspektive onečišćenja rijeka otpadnim vodama iz tekstilne industrije i kožarske industrije u Kini (Xintang), Bangladešu (Daka), Indiji (rijeka Ganges, grad Kanpur), Zimbabveu (rijeka Zambezi) i Indoneziji (Džakarta, rijeka Citarum); obustave proizvodnje trapera u SAD-u (El Paso, Rio Grande); i pozitivnih, održivih rješenja za proizvodnju trapera u Italiji i Španjolskoj. Priča uspostavlja paralele između boje rijeke i boje trapera i neodrživosti proizvodnih praksi moderne odjeće od trapera (na primjer, stonewash). Film se koristi ovim propagandnim tehnikama: emocionalni sendvič, prijenos emocija, tehnika povezanih stavova, upotreba 
stereotipa (zapad prema istoku i jugu), upotrebu autoriteta (aktivisti, dizajneri, znanstvenici), popularnost pojedinih osoba (Jason Priestley) i manipulacija konformizmom.

Posljednji film je Do we change it? Ethical fashion documentary koji je snimljen 2015. u Španjolskoj. Film traje 53 minute, a režirao ga je Carlos Isabel La Moneda. Etična moda predstavljena je kao rješenje problema iz vizure ekoloških, socijalnih i ljudskih dvojbi koje proizlaze iz trenutne masovne proizvodnje brze/jeftine mode. Odnos prema brzoj modi je negativan, odnos prema etičnoj, održivoj modi je izrazito pozitivan. Odnos prema fenomenu mode općenito je umjereno pozitivan. Dokumentarni film podjednako se koristi negativnim i pozitivnim emocionalnim apelima na odgovornost, suosjećanje, brigu o zdravlju i budućnosti. Film prikazuje koncept etične mode putem studija slučaja pokretanja etične modne marke, ili društvenog poduzeća "SÒCIAL - Abetterworld" nevladine organizacije Fundacion Emotiva (Rebeca Pastor i Diego Isabel). Priča o etičnoj modi pripovijeda se i putem drugih pozitivnih slučajeva etičnih modnih marki ili nevladinih organizacija koje promiču koncept etične mode, poput Mantis World (Prama Bhardway), Sunflag (Emmanuel Mgoma), Textile Exchange (Ashley Gill), Toledo Down (Jesus Garcia), Pweye (Carmen Plaza i Phil Wheeler), Nomada Market (Sol Goldentear) i Ananda Pascual. Film nema pripovjedača, priča je ispričana kroz svjedočanstva ljudi koji promiču koncept etične mode. Film se koristi ovim propagandnim tehnikama: emocionalni sendvič, prijenos emocija, tehnika povezanih stavova, upotreba stereotipa (zapad prema istoku i jugu), upotreba autoriteta (aktivisti i dizajneri) i manipulacija konformizmom.

Analiza dokumentarnih filmova pokazala je da se filmovi koji kritiziraju koncept brze mode i promoviraju koncept održive ili etične mode intenzivno koriste propagandnim tehnikama kako bi uvjerili publike u promjenu ponašanja i poduzimanje akcije. Kad je u pitanju uporaba propagandnih tehnika, gotovo svi filmovi koriste se tehnikom emocionalnog sendviča u strukturiranju narativne pozadine priče. Često se koriste i tehnike prijenosa emocija učestalim ponavljanjem neutralnih sadržaja s onim pozitivnim uslijed čega se nastoji postići prijenos pozitivnih emocija prema neutralnom sadržaju, tehnike povezanih stavova, upotreba stereotipa, upotreba autoriteta te popularnosti pojedinih osoba. Narativne tehnike svih filmova prilično su slične bez obzira na to ima li film pripovjedača ili ne i svode se na svjedočanstva ljudi koji su na neki način povezani s fenomenom održive ili brze mode. Argumentacija je dominantno usmjerena na uvjeravanje publike u nužnost promjene njihova načina ponašanja i navika povezanih s kompulzivnom kupnjom jeftine odjeće. Prema tome, filmovi se uglavnom usredotočuju na emocionalne apele brige o zdravlju i budućnosti. Filmovi su daleko manje usredotočeni na motiviranje publika prema pokretanju akcija koje zahtijevaju promjene u proizvodnim praksama neodrživih brzih modnih marki. Osim poziva na osobnu potrošačku odgovornost koja se, pokazala su to dosadašnja istraživanja učinkovitosti okolišnih dokumentarnih filmova, nisu dokazala kao učinkovita, štoviše, prema pojedinim istraživačima čak su i kontraproduktivna, u analiziranim filmovima nisu primijećeni drugi pokušaji integriranja publika. Kod većine analiziranih filmova na odjavnim špicama izostaju čak i pozivi na financijsku podršku ili uključivanje u komunikacijske aktivnosti na društvenim mrežama i medijima, pisanje apela političarima ili uključivanje u aktivnosti civilnog društva kao metoda pritiska. Nezainteresiranost prema aktivnijem uključivanju publika u aktivnosti koje su tema filmova može 
upućivati na manju persuazivnu učinkovitost analiziranih filmova. No za takve tvrdnje potrebno je provesti istraživanja publika.

Kada je riječ o uokvirivanju koncepta brze mode, taj je koncept dominantno predstavljen kao problem, dakle negativno je kontekstualiziran. Suprotno tome koncept održive mode predstavljen je kao rješenje problema te je izuzetno pozitivno kontekstualiziran. Kada je riječ o odnosu analiziranih filmova prema fenomenu mode općenito, taj odnos varira od neutralnog prema pozitivnom. To iznenađuje jer sam fenomen mode podrazumijeva kontinuiranu promjenu trendova koji uzročno-posljedično dovode do neodrživosti mode kao fenomena te je očekivano da se okolišni dokumentarni filmovi jasno negativno odrede prema fenomenu mode općenito.

Iznenađuje i to što se autori filmovi u još većoj mjeri ne koriste apelom straha koji je jedan od najsnažnijih propagandnih apela, posebice u vizualnim medijima koji naraciju grade na binarnim oprekama, problem - rješenje, uništenje - stvaranje, ružno - lijepo, opasno - blagotvorno. Od svih analiziranih filmova jedino se Unravel, najkraći analizirani film i jedini koji je režirala redateljica, dominantno oslanja na pozitivne emocionalne apele ljubavi, suosjećanja te gradi osobnu, ljudsku priču na pozadini osobnog iskustva naratorice filma. To cijelom filmu daje i iznimno humanu, pozitivnu dimenziju. Taj se film od drugih analiziranih filmova razlikuje i po kratkoći trajanja. S obzirom na činjenicu da su sva dosadašnja istraživanja učinkovitosti poruka pokazala da su daleko učinkovitije kratke poruke (Tomić, 2008, str. 166), procjena je autorice i da bi kraće forme okolišnih dokumentarnih filmova bile uspješnije u postizanju propagandnih ciljeva, baš kao što je i uravnotežena kombinacija pozitivnih i negativnih apela djelotvornija od isključive upotrebe pozitivnih ili negativnih apela.

\section{ZAKLJUČAK}

Ovo je istraživanje pokazalo da se analizirani dokumentarni filmovi koji kritiziraju neodržive i promiču održive prakse u modnoj industriji intenzivno koriste propagandnim tehnikama te se dominantno oslanjaju na negativne apele. Funkcija svih analiziranih filmova je pragmatična jer se usredotočuju na konkretan problem - neodrživost današnje industrije brze/jeftine mode koja se manifestira kao onečišćenje okoliša i prirode (vode, tla, zraka), nepoštivanje socijalnih i ljudskih prava radnika u tekstilnoj industriji te lokalnih zajednica u blizini tzv. "sweatshop-ova“, kao i nepravedna distribucija ekonomskih koristi od te moćne industrije. Nije vidljiva konstitutivna ambicija okolišne komunikacije kao alata koji pomaže publici u izgradnji reprezentacije izazova vezanih uz održivost, prirodu i okoliš kao predmeta spoznaje, odnosno nužnosti dubinskih promjena struktura društva u kojem živimo. To je vidljivo iz same činjenice da većina analiziranih filmova ne kritizira fenomen mode kao takve, kapitalistički sustav koji potiče konzumerizam te hegemoniju koja počiva na "ozakonjenim“ strukturnim nepravdama. Izuzetak je film True Cost koji je i jedini film financiran kao crowd funding projekt upravo kako bi bio neovisan o mogućim utjecajima financijera filma. True Cost je i jedini film koji potpuno otvoreno kritizira kapitalizam. Ostali filmovi traže kozmetičke promjene modne industrije, a ne korjenite promje- 
ne sustava koji je doveo do pojave tog neodrživog fenomena. Osim toga, kod svih propagandnih sadržaja potrebno je imati na umu krajnje ciljeve koje propagandisti žele postići. S obzirom na činjenicu da je The Next Black sponzorirala korporacija AEG, propagandne ciljeve tog filma koji promiče održivu modu kao tehnološki superiornu modu budućnosti treba tražiti u promociji specifičnog proizvoda tvrtke - nove generacije ekoloških perilica rublja. Kada je u pitanju Slow Down Fast Fashion, primjetno je da se vuna i odjevni proizvodi od vune intenzivno promoviraju, da je narator filma proizvođač sira koji je povezan s uzgojem ovaca, da se ovce u filmu pojavljuju nekoliko puta. Ujedinjeno Kraljevstvo također ima dugu tradiciju i jaku industrijsku proizvodnju vunenih tekstila. Nemoguće je ne primijetiti da Unravel na prilično uljepšan način prikazuje proizvodne prakse u tvornici koja reciklira zapadnjačku odjeću, tako da je moguće da taj film zagovara interese tvornice recikliranog tekstila. Slični se elementi mogu naći i u drugim analiziranim filmovima, npr. River Blue promovira proizvođača održivog trapera, a Do we change it? Ethical fashion documentary promovira nekolicinu španjolskih etičnih modnih marki. Dodatne sumnje u takav tip namjera potiče i činjenica da većina analiziranih filmova nema transparentno navedene financijere filma, što dovodi u pitanje etičnost tih proizvoda ekokinematografije.

Kada je riječ o učinkovitosti utjecaja proučenih filmova na publike, na temelju broja pregleda na YouTube kanalu samih filmova ili propagandnih najava filmova nije moguće donijeti zaključke. Kako bi se donijeli zaključci o njihovoj učinkovitosti, trebalo bi provesti istraživanje prikladnim metodama istraživanja publika, odnosno medijskih učinaka na publike. Sudeći prema rezultatima dosadašnjih istraživanja, preliminarna hipoteza bila bi da su ti filmovi učinkoviti u smislu informiranja i uvjeravanja, no nisu učinkoviti u smislu pokretanja na akciju, odnosno promjene individualnih ponašanja. Stoga je preporuka autorima takvih filmova da osim primjene propagandnih tehnika te uravnoteženog omjera negativnih i pozitivnih apela, pokušaju što je moguće više integrirati publike u svoje sadržaje, posebice uz pomoć digitalnih komunikacijskih kanala. Neke od mogućih taktika za integriranje publika su organiziranje e-rasprava s ciljanim javnostima, dvosmjerno komuniciranje s ciljanim javnostima putem društvenih mreža i/ili mrežnih stranica, organiziranje različitih digitalnih ili kontaktnih događanja (promocija filmova) otvorenih za sve zainteresirane, upotreba različitih platformi za interaktivnu komunikaciju s građanima (zabavne igre, kvizovi, nagradne igre, posebice interaktivne nagradne igre). Osim toga, preporuka je i da duljina filmova bude između pola sata i maksimalno sat vremena te da se naracija oslanja na manji broj toplih, osobnih priča koje imaju jasan okvir u master mitovima, te da se izbjegava naracija koja se temelji na svjedočanstvima velikog broja sudionika.

Zaključno, dokumentarni filmovi moćan su alat za promicanje održivih praksi u modnoj industriji koji se, unatoč proklamiranoj etici okolišne komunikacije, koriste propagandnim instrumentima koje mnogi teoretičari smatraju neetičnim komunikacijskim praksama. Ali ako se propagandne tehnike smatraju komunikacijskim alatima koji nemaju pozitivnu ili negativnu, već samo pragmatičnu vrijednost, postoje brojne mogućnosti za poboljšanje primjene propagandnih tehnika u modnim okolišnim dokumentarnim filmovima, kako bi se poboljšala učinkovitost njihova utjecaja na publike. 


\section{Literatura}

$>$ Akers, B. (Redatelj). (2016). Slow Down Fast Fashion. [Film]. Journeyman Pictures. $>$ Bernays, E. (1947). The Engineering of Consent. The Annals of the American Academy, 250(1), $113-120$.

>Blewitt, J. (2017). Razumijevanje održivog razvoja. Naklada Jesenski i Turk.

$>$ Booker, C. (2006). The Seven Basic Plots: Why We Tell Stories. Continuum.

>Bordwell, D. i Thompson, K. (2011). Minding Movies: Observations on the Art, Craft, and Business of Filmmaking. The University of Chicago Press.

$>$ Chomsky, N. (2002). Mediji, propaganda i sistem. Što čitaš?

>Clean Clothes Campaign (n.d). Rana Plaza. Preuzeto 17.10.2021., s https://cleanclothes.org/

campaigns/past/rana-plaza

$>$ Cline, E.L. (2012). Overdressed: The Shockingly High Cost of Cheap Fashion. Portfolio/Penguin.

$>$ Cox, R. (2007). Nature's "Crisis Disciplines": Does Environmental Communication Have an Ethical

Duty?. Environmental Communication, 1(1), 5-20.

$>$ Cox, R. (2010). Environmental Communication and the Public Sphere. Sage Publications, Inc.

$>$ Dworsky, D. (Redatelj). (2014). The Next Black. [Film]. AEG.

$>$ European Parliament (2020, prosinac). The impact of textile production

and waste on the environment (infographic). Preuzeto 17.10.2021., s https://

www.europarl.europa.eu/news/en/headlines/society/20201208STO93327/

the-impact-of-textile-production-and-waste-on-the-environment-infographic

$>$ Goffman, E. (1986). Frame Analysis: An Essay on the Organization of Experience. Northeastern University Press.

$>$ Grant, B.K. i Sloniowski, J. (1998). Documenting the Documentary: Close Readings of Documentary Film and Video. Wayne State University Press.

$>$ Grierson, J. (1946). Postwar Patterns. Hollywood Quarterly, 1(2), 160.

$>$ Gupta, M. (2012). (Redateljica). Unravel. [Film]. Soul Rebel Films.

$>$ Hardy, F. (1946). Grierson on Documentary. Harcourt Brace.

$>$ Harness, H. i Drossman, H. (2011). The environmental education through filmmaking project.

Environmental Education Research, 17(6), 829-849.

$>$ Heimlich, J.E. (2010). Environmental education evaluation: Reinterpreting education as a strategy for meeting mission. Evaluation and Program Planning, 33, 180-185.

$>$ Hethorn, J. i Ulasewicz, C. (2009). Sustainable Fashion: Why Now?. Fairchild Books.

$>$ Holy, M. i Borčić, N. (2018). Information, Consumerism and Sustainable Fashion. U I. Ljumović, i A. Éltető, (Ur.), Sustainable Growth and Development in Small Open Economies (str. 179-195). Beograd: Institute of World Economics, Centre for Economic and Regional Studies of the Hungarian Academy of Sciences.

>Hansmann, R. Miegb, H.A. i Frischknechta, P. (2012). Principal sustainability components: empirical analysis of synergies between the three pillars of sustainability. International Journal of Sustainable Development \& World Ecology, 19(5), 451-459.

$>$ Hoskins, T.E. (2015). Zašiveno do bola: Antikapitalistička knjiga mode. Sandorf \& Mizantrop i CIMO. $>$ Howell, R.A. (2014). Investigating the long-term impacts of climate change communications on individuals' attitudes and behaviour. Environment and Behavior, 46(1), 70-101. https://doi. org/10.1177/0013916512452428

$>$ Hungerford, H.R. i Volk, R.L. (1990). Changing learner behavior through environmental education. Journal of Environmental Education, 21, 8-21. https://doi.org/10.1080/00958964.1990.10753743 >Jacobsen, G.D. (2011). The Al Gore effect: An inconvenient truth and voluntary carbon offsets. Journal of Environmental Economics and Management, 61, 67-78.

$>$ Janpol, H.L. i Dilts, R. (2016). Does viewing documentary films affect environmental perceptions and behaviors?. Applied Environmental Education \& Communication, 15(1), 90-98. https://doi.org/10.1 080/1533015X.2016.1142197

$>$ Jestratijevic, I. i Rudd, N.A. (2018). Six Forms of Sustainable Fashion. Trends in Textile \& Fash Design, 2(4), 220-222. https://doi.org/10.32474/LTTFD.2018.02.000145 
$>$ Karlin, B. i Johnson, J. (2011). Measuring impact: The importance of evaluation for documentary film campaigns. M/C Journal, 140(6), 1-8.

$>$ Kellstedt, P.M., Zahran, S. i Vedlitz, A. (2008). Personal efficacy, the information environment and attitudes toward global warming and climate change in the United States. Risk Analysis, 28, 1-14. $>$ Kunczik, M. (2006). Odnosi sjavnošću: koncepti i teorije. Fakultet političkih znanosti.

$>$ Kunczik, M. i Zipfel, A. (2006). Uvod u znanost o medijima i komunikologiju. Zaklada Friedrich Ebert. $>$ La Moneda, C.I. (Redatelj). (2015). Do we change it? Ethical fashion documentary. [Film]. Zimoneda Producciones.

>Lee-Wright, STR. (2010). The Documentary Handbook. Routledge.

$>$ Lule, J. (2001). Daily News, Eternal Stories. The Mythological Role of Journalism. The Guilford Press.

$>$ Lury, C. (1996). Consumer Culture. Polity Press.

$>$ Mcllvride, D. i Williams, R. (Redatelji). (2017). River Blue. [Film]. Paddle Production Inc.

>Ministarstvo gospodarstva i održivog razvoja (2018, rujan). Sedmo nacionalno izvješće i treće dvogodišnje izvješće Republike Hrvatske prema Okvirnoj konvenciji Ujedinjenih naroda o promjeni klime (UNFCCC). https://mzoe.gov.hr/UserDocsImages/KLIMA/SZOR/7\%20Nacionalno\%20 izvje\%C5\%A1\%C4\%87e\%20prema\%20UNFCCC.pdf $>$ Ministarstvo gospodarstva i održivog razvoja (2020, prosinac). Izvješće o gospodarenju otpadnim tekstilom i otpadnom obućom u 2019. godini. http://www.haostr.hr/sites/default/files/uploads/ dokumenti/021_otpad/Izvjesca/OTP_Izvje\%C5\%A1\%C4\%87e_tekstil_2019\%20(final\%20WEB).pdf $>$ Morgan, A. (Redatelj). (2015). True Cost. [Film]. Untold Creative i Life Is My Movie Entertainment. $>$ Niinimäki, K. (2013). Sustainable fashion: New approaches. Aalto ARTS Books.

$>$ Nolan, J.M. (2010). "An Inconvenient Truth" Increases Knowledge, Concern, and Willingness to Reduce Greenhouse Gases. Environment and Behavior, 42(5), 643-658. https://doi.

org/10.1177/0013916509357696

$>$ Previšić, J. (2011). Leksikon marketinga. Ekonomski fakultet u Zagrebu.

$>$ Remy, N., Speelman, E. i Swartz, S. (2016). Style that's sustainable: A new fast-fashion formula.

Preuzeto 12.12.2021., s https://www.mckinsey.com/business-functions/sustainability/our-insights/ style-thats-sustainable-a-new-fast-fashion-formula

$>$ Ribeiro Rosa, A.M. (2016). Circular Economy in the Clothing Industry: Challenges and Strategies. Preuzeto 17.10.2021., s http://www.diva-portal.org/smash/get/diva2:1037685/FULLTEXT01.pdf $>$ Šiber, I. (2003). Politički marketing. Politička kultura.

$>$ Škarica, M. (2012). Propaganda kroz europsku povijest. Synopsis.

$>$ Tkalac Verčič, A., Sinčić Ćorić, D., i Pološki Vokić, N. (2014). Priručnik za metodologiju istraživanja u društvenim djelatnostima. M.E.STR.

$>$ Tkalac Verčič, A. (2015). Odnosi sjavnošću. HUOJ.

$>$ Tobias, R. (1993). 20 master plots (and how to build them). Writer's Digest Books.

$>$ Tomić-Koludrović, I. i Leburić, A. (2002). Sociologija životnog stila. Naklada Jesenski i Turk.

>Tomić, Z. (2008). Odnosi sjavnošću. Teorija i praksa. Synopsis.

$>$ Webb, J. (2012). Climate Change and Society: The Chimera of Behaviour Change Technologies. Sociology, 46(1), 109-125. https://doi.org/10.1177/0038038511419196

$>$ Willoquet-Maricondi, P. (2010). Shifting Paradigms: from environmentalist film to ecocinema. U P. Willoquet-Maricondi (Ur.) Framing the World: Explorations in Ecocinema and Film (str. 43-61). University of Virginia Press. 


\section{DOCUMENTARIES AS INSTRUMENTS OF SUSTAINABLE FASHION PROMOTION}

\section{Mirela Holy}

ABSTRACT Sustainable fashion is socially and environmentally responsible fashion, economically successful and ethical in relation to nature, other living beings and people. The results of the research of Croatian designers' attitudes regarding the concept of sustainable fashion have shown that most of the respondents get acquainted with this concept through documentaries (Holy \& Borčić, 2018), which is not surprising because there are many attractive documentaries on the topic of fast fashion unsustainability and promotion of sustainable concepts in the fashion industry. The paper explores how six documentary films frame the concept of sustainable fashion and the concept of fast/cheap fashion, which emotional appeals are used in films, how narrative is constructed and how fashion in general is presented. Content analysis was conducted on the following documentaries: True Cost, The Next Black, Slow Down Fast Fashion, Unravel, River Blue and Do we change it? Ethical fashion documentary. Research has shown that documentaries about the fashion industry use manipulative persuasion techniques but insufficiently integrate audiences, which can affect their effectiveness. 